\title{
An Assay for Detection of Uropathogenic Escherichia coli Biofilm using Calcofluor
}

\author{
*Flores-Encarnación, M. ${ }^{1}$, Guzmán-Flores, J.E. ${ }^{1}$, Amador-Bravo, D. ${ }^{1}$, \\ Aguilar-Gutiérrez, G.R. ${ }^{2}$ and Cabrera-Maldonado, C. $^{3}$ \\ ${ }^{1}$ Laboratorio de Microbiología Molecular y Celular. Biomedicina. Facultad de Medicina, Benemérita \\ Universidad Autónoma de Puebla. Puebla, Puebla. México. \\ ${ }^{2}$ CISEI, Instituto Nacional de Salud Pública. Cuernavaca, Morelos. México. \\ ${ }^{3}$ Dpto. de Microbiología, Facultad de Ciencias Químicas. Benemérita Universidad Autónoma de \\ Puebla. Puebla, Puebla, México. \\ mflores31@hotmail.com
}

\begin{abstract}
The biofilm is a community of microorganisms found adhered to a surface, growing in an exopolysaccharide matrix whose composition varies between bacterial species. It has been reported that chronic infections are closely related to the formation of biofilm; it represents a defense mechanism in which bacterial cells survive the bacterial stress, to host immune response and even resist some antimicrobial agents. The calcofluor white is a fluorophore that binds to glycosidic bonds $\beta$ (1-3) and $\beta$ (1-4), generally used for identifying various species of fungi. This paper shows an assay to the detection of uropathogenic E. coli biofilm using the calcofluor staining.
\end{abstract}

Keywords: Biofilm, Detection, Bacteria, Calcofluor white, Exopolisacharide.

\section{INTRODUCTION}

The biofilm is a community of microorganisms that are attached to a living or inert surface, having a extracellular matrix synthesized in the biofilm. Also it can also be found in a gas-liquid interface (Costerton, 1999; Costerton et al., 1995; Characklis and Marshall, 1990; Donland, 2002; Donland and Costerton, 2002; Flores-Encarnación et al., 2014; Hall-Stoodley et al., 2008; Nazar, 2007). The biofilm consists of an extracellular matrix composed of proteins, DNA, exopolysaccharides, bacteria and water (98\% volume approximately) (Nazar, 2007; Sack et al., 2014). The water, nutrients and waste pass through small channels formed between the bacterial extracellular matrix (FloresEncarnación et al., 2016; Kalbbach et al., 1997; Nazar et al. 2007; Zhang et al., 2012). The history of Microbiology has focused on studying microorganisms in planktonic state (those free-floating cells that are dispersed in the environment where they grow) (Costerton, 1999; Costerton et al., 1995). However, it has been observed that there are metabolic differences between cells in biofilm state and planktonic state (Donland, 2002; Nazar, 2007). The biofilm represents an old strategy prokaryotic survival which offers advantages such as protection against environmental fluctuations (temperature and $\mathrm{pH}$ changes, nutrient concentrating and facilitating the removal of waste (Donland and Costerton, 2002; Post, 2001).

Currently, bacterial infectious diseases have gained particular interest because of their capacity to produce chronic infections, which in many cases respond poorly to treatment with antibiotics (Castrillón et al., 2010; Donland and Costerton, 2002; Foxman, 1990). It has been reported that the biofilm allows bacteria to be more resistant to action of antibiotics and even they are able to evade the host immune response (Bjarnsholt, 2013; Nazar, 2007; Stewart and Costerton, 2001). It has been reported that one of the factors that has contributed to the development of chronic infections and repeat offenders is the biofilm formation. So it has been observed the formation of bacterial biofilm in otitis, endocarditis, periodontitis, osteomyelitis, cistitis, orthopedic devices, among others (Barbara and Rabih, 2004; Castrillón et al., 2010; Christensen et al., 1985; Foxman, 1990; Kanamaru et al., 2006; Post, 2001). The bacteria commonly found in biofilm and associated with infectious processes are Pseudomonas aeruginosa, Staphylococcus aureus, S. epidermidis, Ureaplasma urealyticum, some fungi species belonging to the genus Candida sp. and Aspergillus sp. (Barbara and Rabih, 2004; Castrillón et al., 2010; Donland and Costerton, 2002; Foxman, 1990; Foxman et al., 2000; Kanamaru et al., 2006). 
One of the most common techniques for the detection of biofilm is the plaque assay using violet crystal described by Christensen et al., (1985) and O'Toole and Kolter (1998). However, not all clinical diagnostic laboratories have this technology. The calcofluor white is a fluorophore which binds to bonds $\beta$ (1-3) and $\beta$ (1-4) of exopolysaccharides (Ramos et al., 2006). It has been widely used for identifying fungi and yeast (García et al., 2001; Ramos et al., 2006). The present study aimed to assay of a rapid method for detection of bacteria forming biofilm using calcofluor white staining.

\section{MATERIAL AND MethodS}

\subsection{Bacterial Strain}

A strain of uropathogenic Escherichia coli from a clinical isolate was used. As reference E. coli $\mathrm{K} 12$ strain was used. In both cases the strains were stored into cryovials at $-40^{\circ} \mathrm{C}$ until analysis.

\subsection{Culture Conditions and Calcofluor Assay}

The LB broth (Luria Bertani: tryptone $10 \mathrm{~g} / \mathrm{L}$, yeast extract $5 \mathrm{~g} / \mathrm{L}, \mathrm{NaCl} 10 \mathrm{~g} / \mathrm{L}$ ) was used for bacterial culture. The exopolysaccharides of biofilm were stained with calcofluor white according to methodology described by Ramos et al., (2006). For that, a total of $20 \mu \mathrm{L}$ of uropathogenic E. coli and E. coli $\mathrm{K} 12$ overnight incubated starter cultures were extended on $0.02 \%$ calcofluor white/LB agar plates. Plates were incubated at $37^{\circ} \mathrm{C}$ during $24-48$ hours into a chamber to keep moisture. A similar procedure was performed using test tubes containing $0.02 \%$ calcofluor/LB broth. The test tubes were incubated at $37^{\circ} \mathrm{C}$ during $24-48$ hours. The biofilm of gas-liquid interface was evidenced by the addition of $0.1 \%$ crystal violet on the surface of the culture broth. Also it was tested the calcofluor staining in a microplate assay. For that, $10 \mu \mathrm{L}$ of an uropathogenic E. coli overnight incubated starter culture was transferred to a pre-sterilized 96-well polystyrene microtiter plate containing $200 \mu \mathrm{L}$ of $0.02 \%$ calcofluor/LB broth for well. The microtiter plate was incubated for $24-48$ hours at $37^{\circ} \mathrm{C}$. Then, the plates and probe tubes were exposed to UV light and the fluorescence emitted by exopolysaccharides of cells forming biofilm was observed. Assays on all samples were repeated in duplicate.

\subsection{Calcofluor white Staining}

For calcofluor white staining the bacterial sample was obtained from uropathogenic E. coli strain growing on LB agar plate. The sample was placed on a glass slide and then the sample was stained with $0.02 \%$ calcofluor white. The glass slide was incubated at room temperature for $20 \mathrm{~min}$ in the dark and it was then exposed to UV light. The light emission confirmed the presence of exopolysaccharides in the samples. Subsequently, the samples were observed at 40x in a fluorescence microscope using an exciter filter $460 \mathrm{~nm}$ and $500 \mathrm{~nm}$ barrier filter. Assays on all samples were repeated in duplicate.

\section{RESUlTS}

The uropathogenic E. coli and E. coli $\mathrm{K} 12$ strains were grown on $0.02 \%$ calcofluor white/LB agar plates. Plates were incubated at $37^{\circ} \mathrm{C}$ during $24-48$ hours. As shown in Fig. 1A and Fig. 1B, $0.02 \%$ calcofluor not inhibited the growth of uropathogenic E. coli and E. coli K-12 strains on LB agar plates. The cells de E. coli absorbed the calcofluor dye and good growth was recorded. When culture plates were exposed to UV light, cells forming biofilm were identified by fluorescence emission related to presence of exopolysaccharides (Fig. 1C and Fig. 1D). Fluorescence was more intense along the seed line of the bacteria. Furthermore fluorescence on the surface of tested culture medium was observed, which suggested that exopolysaccharides spread in the culture medium. As shown in Fig. 1, the biofilms from uropathogenic $E$. coli and $E$. coli K-12 were recorded. The fluorescence emitted by the control plate (without inoculum) was negligible, so it was found that LB agar components not interfered in the detection of exopolysaccharides by this technique (data not shown). Also the calcofluor staining was carried out in test tubes containing $0.02 \%$ calcofluor/LB broth. The results obtained are shown in Fig. 2. Fig, 2A shows the test tubes containing E. coli in active growing. The biofilm formation of $E$. coli was observed in the gas-liquid interface by adding violet crystal. However, E. coli biofilm was weak and moved to the bottom of the culture medium (Fig. 2A). Fig. 2B and Fig. $2 \mathrm{C}$ show the probe tubes exposed to UV light. The results showed that the fluorescence emission was located at the bottom of the test tubes containinig $E$. coli in active growing and in the bottom walls of the test tube, while the gas-liquid interface showed no significant fluorescence emission. The fluorescence emitted by the culture medium used as control (without inoculum) was 
negligible (Fig. 2B, Fig, 2C, left). The microplate assay for calcofluor staining was done for both strains. Fig. 2D shows the results obtained when the plate was exposed to UV light. In Fig. 2D is shown the fluorescence emitted by $E$. coli cells located in a well of polystyrene microtiter plate. The fluorescence emission was located at the walls and bottom of well containinig E. coli in active growing. The fluorescence emitted by the culture medium used as control (without inoculum) was negligible (Fig. 2D, top). On the other hand, the calcofluor direct staining was carried out from samples of uropathogenic E. coli strain growing on LB agar plates. The sample was placed on a glass slide, it was stained with calcofluor and then exposed to UV light. The Fig. 3A shows the fluorescence obtained from the samples of $E$. coli. As it can be seen, the calcofluor technique quickly detected the fluorescence of cells forming biofilm, confirming the presence of exopolysaccharides in the samples. When the samples were observed at $40 \mathrm{x}$ in a fluorescence microscope, the cell clusters were observed emitting fluorescence (Fig. 3B).

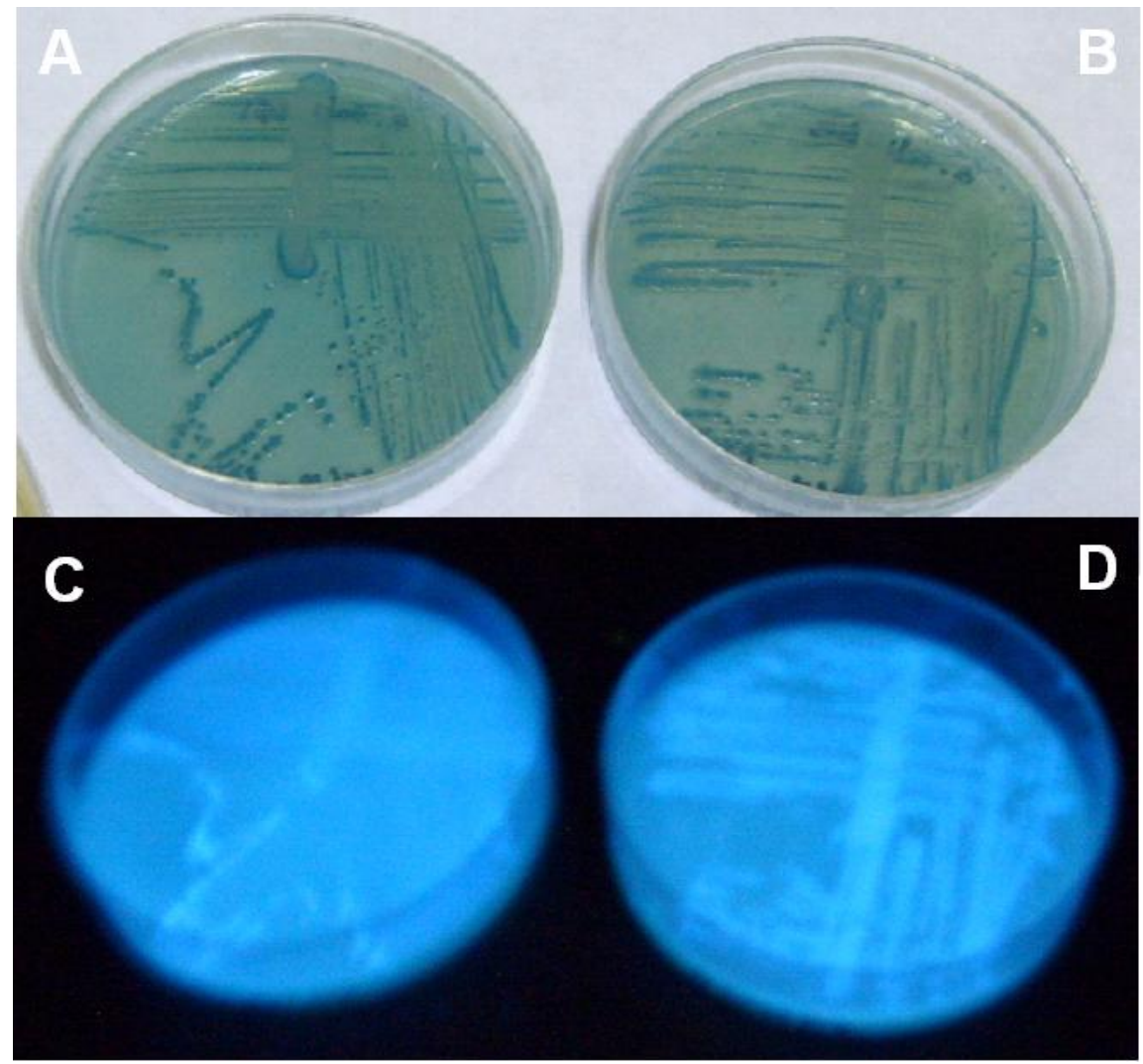

Fig1. The uropathogenic E. coli $(A, C)$ and E. coli $K 12(B, D)$ strains growning on calcofluor/LB agar plates. The plates were not exposed to UV light (A and B). The plates were exposed to UV light $(C$ and $D)$.
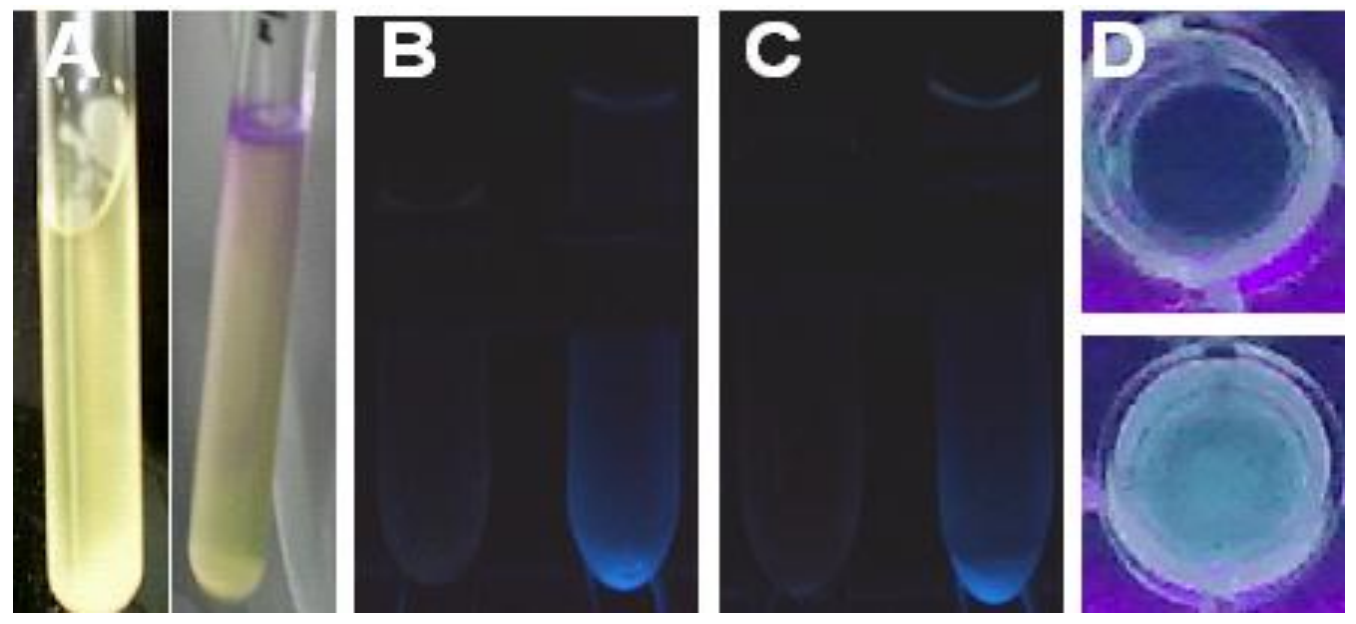

Fig2. The calcofluor staining of uropathogenic E. coli and E. coli K12 forming biofilm in test tubes. Biofilm of $E$. coli observed in the gas-liquid interface (A). Fluorescence emission of uropathogenic E. coli and $E$. coli $K$ 12 (Right: B and C); Fluorescence emission of only culture medium (Left). D. Microplate assay for calcofluor staining; only culture medium (Top) and uropathogenic E. coli forming biofilm in well (Botton). 
Flores-Encarnación, M. et al.

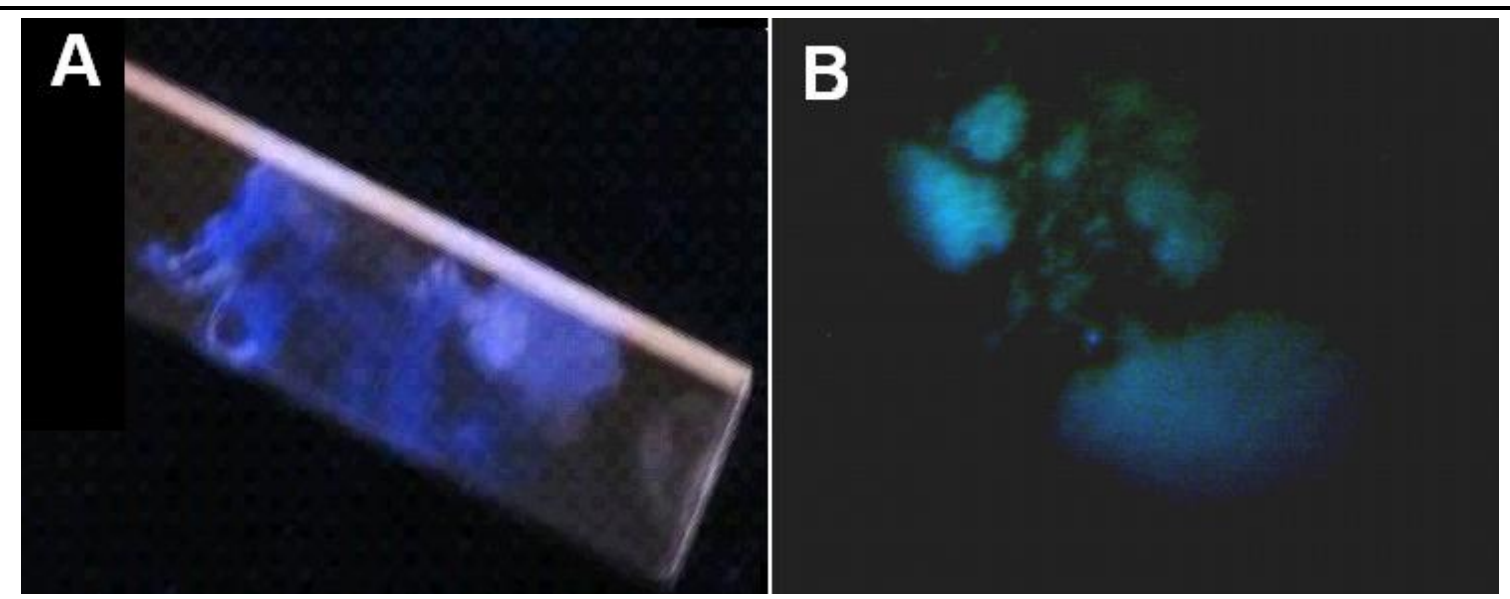

Fig3. The calcofluor direct staining. Uropathogenic E. coli placed on a glass slide and exposed to UV light (A). Cell clusters observed in fluorescence microscope (B).

\section{DisCUSSION}

Bacteria can live in planktonic (free living) or biofilm state. In biofilm, bacteria are attached to a surface, where proliferate themselves, aggregate and secrete exo-polysaccharides and other substances (Naher et al., 2014). Bacteria inside the biofilm show properties that are different from their freeliving state (Costerton, 1999). The biofilm structure confers the bacteria more resistant against environmental stresses, antibiotics and host immune (Donland and Costerton, 2002; Marin, 2009; Serra et al., 2013). On the other hand, it has been reported that bacterial biofilm is measured through a technique using violet crystal; that staining has been reported by many authors. The violet crystal staining provides a biofilm qualitative assay because it evidences the adherence to the walls of the containers used in the assay. The violet crystal stains bacterial organic matter attached to the test surfaces, while calcofluor staining has confirmed that it is indeed biofilm. The calcofluor white is a fluorescent dye that binds in the glycosidic linkages $\beta-(1-3)$ and $\beta-(1-4)$; it is generally used for to observe the exopolysaccharides in biofilm (Ramos et al., 2006). The violet crystal provides a good measure of biofilm mass. However, it does not give a measure of biofilm viability (Welch et al., 2012). In this paper, the production of bacterial exopolysaccharides was indicative of the viability of bacteria forming biofilm. The exopolysaccharides were detected using calcofluor white in cells of uropathogenic E. coli. As shown in Fig. 1, the uropathogenic E. coli and E. coli K-12 strains growth on calcofluor/LB agar plates and the growth not inhibited by calcofluor. The assay showed the viability of the bacteria when the plates were exposed to UV light. By the fluorescence emission the polysaccharides from bacterial strains were observed. This is consistent with studies by other authors in different biological models (Brandl et al., 2011; Eriksson de Rezende et al., 2003; Mathur et al., 2006). It has been reported that calcofluor white binds to cellulose (for example: E. coli exopolysaccharide) (Brandl et al., 2011; Serra et al., 2013). Therefore fluorescence colonies on calcofluor agar denoted the bacterial cellulose production as some authors have described (Monteiro et al., 2009; Zogaj et al., 2001). In this work, biofilm of E. coli in the gas-liquid interface and botton from test tubes was observed as it described in other bacteria (Spiers et al., 2003) (Fig. 2). The fluorescence emission was related with cellulose production for uropathogenic E. coli. As shown in Fig. 2, the uropathogenic E. coli and E. coli K-12 strains formed biofilm in test tubes, however the fluorescence intensity produced by calcofluor was poor. The results showed that $E$. coli biofilm was weak, it moved to the bottom of test tubes and it had poor adherence to glass. In microplate assay, fluorescence intensity emitted by E. coli cells in polystyrene wells was higher than fluorescence emitted by E. coli cells in glass (Fig. 2D). This difference is according with studies reported by other authors (Donland, 2002; Moreira et al., 2015; Ryu and Beuchat, 2005; Van Houdt and Michiels, 2010). Apparently the best result was obtained using polystyrene as support material to do this test. It has been reported that polystyrene is used by bacteria to form biofilm easily (Chaves-Simões et al., 2010). Finally, the uropathogenic E. coli strain extended on a glass slide was stained with calcofluor and then exposed to UV light. The results shown that calcofluor quickly detected to cells forming biofilm by presence of exopolysaccharides. To fluorescence microscope the cells of uropathogenic $E$. coli were organized in clusters (Fig. 3), which is consistent with studies by other authors. Rowe et al., (2010) reported that uropathogenic E. coli forms large biofilm aggregates when it was grown in ironrestricted tissue culture media. 


\section{CONCLUSION}

The calcofluor agar showed significant detection of exopolysaccharide present in biofilms of uropathogenic E. coli. The use of this technique is suggested for rapid detection of bacteria forming biofilm. Also the fluorescence microscopy facilitates identification of biofilm-forming strains, having a corroboration of the presence of bacterial polysaccharides in clusters.

\section{ACKNOWLEDGEMENTS}

Thank to LBM. Pérez-Rodríguez, A.R. from Biomedicina-BUAP, for the valuable technical collaboration for the development of this work. Also at VIEP-BUAP and PRODEP for the facilities provied for the development of this work.

\section{REFERENCES}

[1] Barbara WT and Rabih OD (2004). Role of biofilm in catheter-associated urinary tract infection. Am. J. Infect. Control. 32:177-183.

[2] Bjarnsholt T (2013). The role of bacterial biofilms in chronic infections. APMIS Supl. 121:1-51.

[3] Brandl MT, Carter MQ, Parker CT, Chapman MR, Huynh S and Zhou Y (2011). Salmonella biofilm formation on Aspergillus niger involves cellulose-chitin interactions. PLoS ONE. 6:e25553.

[4] Castrillón RL, Palma RA and Padilla DM (2010). Importancia de las biopelículas en la práctica médica. Dermatol. Rev. Mex. 54:14-24.

[5] Characklis WG and Marshall KC (1990). Biofilms: a basis for an interdisciplinary approach. in Biofilms. Eds Characklis W.G., Marshall K.C. John Wiley and Sons, Inc. New York, N.Y. pp 3-15.

[6] Chaves-Simões L, Simões M and Vieira MJ (2010). Adhesion and biofilm formation on polystyrene by drinking water-isolated bacteria. Antonie van Leeuw. 98:317-329.

[7] Christensen GD, Simpson WA, Younger JJ, Baddour LM, Barrett FF, Melton DM and Beachey EH (1985). Adherence of cogulase negative staphylococci to plastic tissue cultures: a quantitative model for the adherence of staphylococci to medical devices. J. Clin. Microbiol. 22:996-1006.

[8] Costerton JW (1999). Introduction to biofilms. Int. J. Antimicrob. Agents. 11:217-221.

[9] Costerton JW, Lewandoski DE, Cadwell DR, Corber HM and Lappin-Scott H (1995). Microbial biofilms. Annu. Rev. Microbiol. 49:711-745.

[10] Donland R (2002). Biofilms: Microbial life on surfaces. Emerg. Infect. Dis. 8:881-890.

[11] Donland RM and Costerton JW (2002). Biofilms: survival mechanisms of clinically relevant microorganisms. Clin. Microbiol. Rev. 15:167-193.

[12] Eriksson de Rezende CL, Joseph SW, Teicher E, Carr LE, Tall B and Weiner RM (2003). Calcofluor as a fluorescent probe to detect biofilms of foodborne pathogens. J. Food Saf. 23:2533.

[13] Flores-Encarnación M, Aguilar-Gutiérrez GR, Ixtepan-Tejero C, Juárez-Salazar G, MartínezVaquero JL, Cabrera-Maldonado C, Xicohténcatl-Palacios R.C. 2014. Biofilm: a natural mechanism of bacterial resistance. Intern. J. Curr. Res. 6:10420-10424.

[14] Flores-Encarnación M, Jaramillo-Rodríguez JB, Xicohtencatl-Cortés J, Amador-Bravo D, Aguilar-Gutiérrez GR, Cabrera-Maldonado C, León-Tello G, Ruíz-Tagle A, García-López A and Meneses-Sánchez MC (2016). The presence of bacteria forming biofilm in water pipes commonly used at Puebla, México. Inter. J. Curr. Res. 8:25961-25965.

[15] Foxman B (1990). Recurring urinary tract infection: incidence and risk factors. Am. J. Public Health. 80:331-333.

[16] Foxman B, Barlow R, D'Arcy H, Gillespie B and Sobel JD (2000). Urinary tract infection: selfreported incidence and associated costs. Annals of Epidemiol. 10:509-515.

[17] García C, Beltrán M, Guzmán D, León P, Arredondo and Fonseca A (2001). Diagnóstico rápido de dos casos de mucormicosis con tinción de blanco de calcoflúor. Rev. Chil. Infectol. 18:285290. 
[18] Hall-Stoodley L, Costerton JW and Stoodley P (2008). Bacterial biofilms: from the natural environmental to infectious diseases. Nat. Rev. Microbiol. 2:95-108.

[19] Kalbbach S, Manz W and Szewzyk U (1997). Dynamics of biofilm formation in drinking water: phylogenetic affiliation and metabolic potential of single cells assessed by formazan reduction and in situ hybridation. FEMS Microbiol. Ecol. 22:265-279.

[20] Kanamaru S, Kurazono H, Terai A, Monden K, Kumon H, Mizunoe Y, Ogawa O and Yamamoto S (2006). Increased biofilm formation in Escherichia coli isolated from acute prostatitis. Int. J. Antimicrob. Agents. 28S:S21-S25.

[21] Marin C (2009). Biofilm development capacity of Salmonella strains isolated in poultry risk factors and their resistance against desifectants. Poultry Sci. 88:424-431.

[22] Mathur T, Singhal S, Khan S, Upadhyay DJ, Fatma T and Rattan A (2006). Detection of biofilm formation among the clinical isolates of staphylococci: an evaluation of three different screening methods. Indian J. Med. Microbiol. 24:25-29.

[23] Monteiro C, Saxena I, Wang X, Kader A, Bokranz W, Simm R, Nobles D, Chromek M, Brauner A, Brown RM and Römling U (2009). Characterization of cellulose production in Escherichia coli Nissle 1917 and its biological consequences. Environ. Microbiol. 11:1105-1116.

[24] Moreira JMR, Simões M, Melo MF and Mergulhão FJ (2015). Escherichia coli adhesion to surfaces-a thermodynamic assessment. Colloid Polym. Sci. 293:177-185.

[25] Nazar CJ (2007). Biofilms bacterianos. Rev. Otorrinolaringol. Cir. Cabeza Cuello. 67: 61-72.

[26] Naher J, Chowdhury SA, Mamun AA, Mahmud N, Sumí W and Khan RA (2014). A comparative study on the biofilm formation of Enterobacter agglomerans and Serretia rubideae in different environmental parameter under single culture condition. Open J. Med. Microbiol. 4:70-76.

[27] O'Toole G. and Kolter R (1998). Flagellar and twitching motility are necessary for Pseudomonas aeruginosa biofilm development. Mol. Microbiol. 30:295-304.

[28] Post JC (2001). Direct evidence of bacterial biofilms in otitis media. Laryngosc. 111:2083-2094.

[29] Ramos L, Mellado S, Ramadán S, Bulacio L and López C (2006). Empleo de blanco de calcoflúor para el estudio de las especies de Malassezia por microscopia directa. Rev. Argent. Microbiol. 38:4-8.

[30] Rowe MC, Withers HL and Swift S (2010). Uropathogenic Escherichia coli forms biofilm aggregates under iron restriction that disperse upon the supply of iron. FEMS Microbiol. Lett. 307:102-109.

[31] Ryu JH and Beuchat LR (2005). Biofilm formation by Escherichia coli O157:H7 on stainless steel: effect of exopolysaccharide and curli production on its resistance to chlorine. Appl. Environ. Microbiol. 71:247-254.

[32] Sack EL, van der Wielen PW and van der Kooij D (2014). Polysaccharides and proteins added to flowing drinking water at microgram-per-liter levels promote the formation of biofilms predominated by bacteroidetes and Proteobacteria. Appl. Environ. Microbiol. 80:2360-2371.

[33] Serra DO, Richter AM and Hengge R (2013). Cellulose as an architectural element in spatially structured Escherichia coli biofilms. J. Bacteriol. 195:5540-5554.

[34] Spiers AJ, Bohannon J, Gehrig SM and Rainey PB (2003). Biofilm formation at the air-liquid interface by the Pseudomonas fluorescens SBW25 wrinkly spreader requires an acetylated form of cellulose. Mol. Microbiol. 50:15-27.

[35] Stewart PS and Costerton JW (2001). Antibiotic resistance of bacteria in biofilms. Lancet. 385: $135-138$.

[36] Van Houdt R and Michiels CW (2010). Biofilm formation and the food industry, a focus on the bacterial outer surface. J. Appl. Microbiol. 2010:1-15.

[37] Welch K, Cai Y and Strømme M (2012). A method for quantitative determination of biofilm viability. J. Funct. Biomater. 3:418-431.

[38] Zhang M, Liu W, Nie X, Li C, Gu J, and Zhang C (2012). Molecular analysis of bacterial communities in biofilms of a drinking water clearwell. Microbes Environ. 27:443-448.

[39] Zogaj X, Nimtz M, Rohde M, Bokranz W and Romling U (2001). The multicellular morphotypes of Salmonella typhimurium and Escherichia coli produce cellulose as the second component of the extracellular matrix. Mol. Microbiol. 39:1452-1463. 